\title{
PERANCANGAN APLIKASI PELAYANAN E-COMMERCE TANAMAN HIAS BERBASIS ANDROID
}

\author{
Sajiah $^{1}$, Haris Tehuayo ${ }^{2}$, Labusab $^{3}$ \\ ${ }^{1}$ Teknik Informatika, Universitas Islam Makassar \\ Sajiah.dty@uim-makassar.ac.id \\ ${ }^{2}$ Teknik Informatika, Universitas Islam Makassar \\ harisristo02@gmail.com \\ ${ }^{3}$ Pendidikan Teknik Elektronika, Universitas Negeri Makassar \\ ochalabusab@unm.ac.id
}

\begin{abstract}
ABSTRAK
Dalam melakukan proses pemasran $e$-commerce produk pertanian, aplikasi content manejemen sistem dapat digunakan sebagai salah satu alternatif dalam menyampaikan informasi produk-produk dalam bidang pertanian, sehingga keterbatasan dalam melakukan transaksi penjualan produk-produk pertanian dan teratasi, dan dapat menciptakan sistem penjualan yang lebih efektif, efisien, dan dapat meningkatkan pelayanan pelanggan dalam melakukan pemasaran melalui aplikasi dengan membuat sistem penjualan berbasis aplikasi android yang akan membantu efisiensi dan efektifitas kerja [1]. Adapun obyek penilitian ini adalah pemanfaatan perancangan aplikasi berbasis android sebagai alat untuk memasarkan hasil produkproduk pertanian yaitu tanaman hias, sedangkan yang menjadi subyek dalam penilitian ini adalah hasil dari produk pertanian [2].
\end{abstract}

Kata Kunci: Perancangan , E-Comumerce, Berbasis Android

\section{DESIGN OF ANDROID-BASED ORNAMENTAL PLANT E-COMMERCE SERVICES APPLICATION}

\begin{abstract}
In carrying out the process of marketing e-commerce agricultural products, the application of content management systems can be used as an alternative in conveying product information in the agricultural sector, so that the limitations in conducting sales transactions for agricultural products are resolved, and can create a more efficient sales system. effective, efficient, and can improve customer service in marketing through applications by creating an android application-based sales system that will help work efficiency and effectiveness [1]. The object of this research is the use of android-based application design as a tool to market agricultural products, namely ornamental plants, while the subjects in this research are agricultural products [2].
\end{abstract}

Keyowrd: Design , E-Commerce, Android Based 


\section{PENDAHULUAN}

Indonesia merupakan salah satu Negara dengan populasi penduduk terbesar didunia. Keadaan ini tidak selalu merugikan, melainkan memberikan keuntungan besar bagi indonesia. Oleh karena itu Negara Indonesia merupakan sebuah pasar potensial bagi dunia bisnis dan perdagangan. Semua itu dapat dilihat dari banyaknya perusahaan komersial yang ada diseluruh penjuru Indonesia, bersaing untuk menguasai pangsa pasar untuk mengatur stategis bisnisnya masing-masing, salah satunya dengan menmanfaatkan TI secara optimal untuk mendukung berbagai kegiatan. Sulawesi Selatan adalah salah satu Provinsi di Indonesia yang terletak di pulau Sulawesi dengan Makassar sebagai ibu kotanya [1] .

Di Sulawesi Selatan khususnya kota Makassar banyak terdapat UKM yang bergerak dalam berbagai usaha dan bisnis. Salah satunya adalah $C V$. Ary Gasebo yang terletak di jalan Danau Tanjung bunga. Yang bergerak dalam usaha Penjualan tanaman hias, selama ini banyak memberikan kontribusi yang sangat signifikan dalam memacu pertumbuhan perekonomian di kota Makassar. Hal itu disebabkan karena semua UKM tersebut banyak menyerap tenaga kerja, sehingga dapat menurunkan tingkat penganguran, akan tetapi $C V$. Ary Gasebo ini juga banyak mengalami permasalahan antara lain dalam penjulan. Selain itu juga pengelolaan yang kurang profosional, maupun strategi promosi dan pemasaran suatu produk. Tujuannya semua itu adalah agar perusahan dapat meningkatkan omsetnya. Selain itu CV. Ary Gasebo belum mengimplementasikan strategi dan sistem pemasaran yang belum mendukung. Sehingga $C V$. Ary Gasebo mengalami kesulitan dalam memasarkan produk yang produksinya. Dengan adanya sarana teknologi yang dapat diakses oleh pelanggan, salah satunya dengan menggunakkan sarana teknologi seperti Website, Media Interaktif Berbasis Android, Media sosial dan instagram dan aplikasi lainnya yang dapat diakses secara online. Semua Jaringan internet dapat dimanfaatkan dan memfasilitasi setiap manusia di penjuru dunia untuk berhubungan satu sama lain tanpa dibatasi oleh ruang dan waktu. Tidak dipungkiri sekarang ini bahwa internet sudah menjadi suatu kebutuhan bagi masyarakat.

Perancangan [2] merupakan suatu aktivitas rekayasa perangkat lunak yang dikerjakan dengan mengunakan teknik yang bervariasi serta menyediakan rincian mengenai arsitektur dari perangkat lunak, struktur data, dan tampilan yang seringkali bersifat struktural. Tujuan perancangan adalah menghasilkan model atau representasi entitas yang akan dibangun.

Tujuan perancangan [3] sebagai berikut:

1. Memenuhi spesifikasi fungsional.

2. Memnuhi batasan-batasan media target implementasi, target sistem komputer.

3. Memenuhi kebutuhan-kebutuhan rancangan yang di kehendaki.

4. Memenuhi keterbatasan-keterbatasan proses perancangan seperti lama atau biaya.

Didukung secara resmi oleh lingkungan pengembangan terpadu (IDE) Eclipose, yang menggunakan plugin Android Development Tools (ADT) [4].

Menurut kamus besar bahasa Indonesia,layanan berarti membantu menyiapkan atau mengurus apa-apa yang diperlukan seseorang [5]. Menurut Kotler pelayanan adalah pemberian jasa kepada pelanggan sesuai dengan kebutuhannya. Dikatakan pula bahwa jasa dapat didefinisikan sebagai kegiatan atau manfaat yang dapat diberikan oleh satu pihak kepada pihak lainnya yang pada dasarnya tidak berwujud dan tidak pula berakibat pemilikan sesuatu dan produksinya dapat atau tidak dapat dikaitkan dengan suatu produk fisik [6].

Kata kualitas mengandung banyak definisi dan makna karena orang yang berbeda akan mengartikannya secara berlainan, seperti kesesuaian dengan persyaratan atau tuntutan, kecocokan untuk pemakaian perbaikan berkelanjutan, bebas dari kerusakan atau cacat, pemenuhan kebutuhan pelanggan, melakukan segala sesuatu yang membahagiakan. Dalam perspektif TQM (Total Quality Management) kualitas dipandang secara luas, yaitu tidak hanya aspek hasil yang ditekankan, tetapi juga meliputi proses, lingkungan dan manusia [7].

Electronic Commerce di definisikan sebagai proses pembelian dan penjualan produk, jasa, dan informasi yang dilakukan secara elektronik dengan memanfaatkan jaringan computer. Salah satu jaringan yang digunakan adalah internet. Electronic Commerce (Perniagaan Elektronik), sebagai bagian dari Electronic Business bisnis yang dilakukan dengan menggunakan electronic transmission [8].

Pengertian MySQL adalah, "MySQL merupakan software yang tergolong database server dan bersifat Open Source. Open Source menyatakan bahwa software ini dilengkapi dengan source code (kode yang dipakai untuk membuat MySQL), selain tentu saja bentuk executable-nya atau kode yang dapat dijalankan secara langsung dalam sistem operasi, dan bisa diperoleh dengan cara mengunduh di Internet secara gratis [9]. 
Menurut [10] Javascript adalah suatu bahasa pemograman yang dikembangkan untuk dapat berjalan pada web browser" Javascript adalah bahasa script (scripting language) merupakan instruksi perintah yang digunakan untuk mengendalikan beberapa dari sistem operasi. Kode javascript biasanya dituliskan dalam bentuk fungsi yang ditaruh ditag yang dibuka dengan tag.

\section{METODOLOGI PENELITIAN}

Metode yang digunakan dalam penelitian ini adalah sistem SDLC metode (Sistem Development Life Cycle) atau sering disebut sebagai pendekatan air terjun (waterfall). Dengan judul perancangan Aplikasi pelayanan e-commerce tanaman hias sabana berbasis android, Peneliti menggunakan metode SDLC (Sistem Development Life Cycle) untuk merancang aplikasi yang berbasi android yang digunakan di CV. Ary Gasebo untuk pembelian tanaman hias yang berbasis android.

\section{Alat Dan Bahan}

Perangkat keras (Hadware) dan perangkat lunak (Software) yang digunakan dalam perancangan aplikasi ini yaitu:

\begin{tabular}{|c|c|c|c|c|}
\hline \multirow[t]{2}{*}{ No } & \multicolumn{2}{|c|}{ Alat penelitian } & \multicolumn{2}{|c|}{ Bahan penelitian } \\
\hline & Nama & $\begin{array}{l}\text { Type } \\
\text { data }\end{array}$ & Nama & Type data \\
\hline 1. & Prosessor & $\begin{array}{l}\text { Intel(R) } \\
\text { core }(\mathrm{TM})\end{array}$ & Xатpp & Web server \\
\hline 2. & Page file & $\begin{array}{l}\text { 4996MB } \\
\text { used, } 902 \\
\text { avalable }\end{array}$ & Php & $\begin{array}{l}\text { Web } \\
\text { programing }\end{array}$ \\
\hline 3. & Memory & $\begin{array}{l}\text { 4098MB } \\
\text { RAM }\end{array}$ & MySQL & Database \\
\hline 4. & Hardisk & 1 Tera & $\begin{array}{l}\text { Android } \\
\text { studio }\end{array}$ & Text editor \\
\hline 5. & & & $\begin{array}{l}\text { Windows } \\
10 \text { pro } \\
64 \text {-bit }\end{array}$ & $\begin{array}{l}\text { Operating } \\
\text { system }\end{array}$ \\
\hline 6. & & & $\begin{array}{l}\text { OS } \\
\text { android }\end{array}$ & $\begin{array}{l}\text { Android } \\
\text { lolipop }\end{array}$ \\
\hline
\end{tabular}

\section{HASIL DAN PEMBAHASAN}

\section{a. Perancangan antar muka aplikasi}

Pada perancangan antar muka deftar member, user akan di hadapkan pada pengisian data sebagai syarat untuk menjadi member/pengguna aplikasi, pengisisan data di mulai dari nama lengkap, username, password, tanggal lahir, jenis kelamin, dan alamat. Selanjutnya akan dihadapkan di proses login.

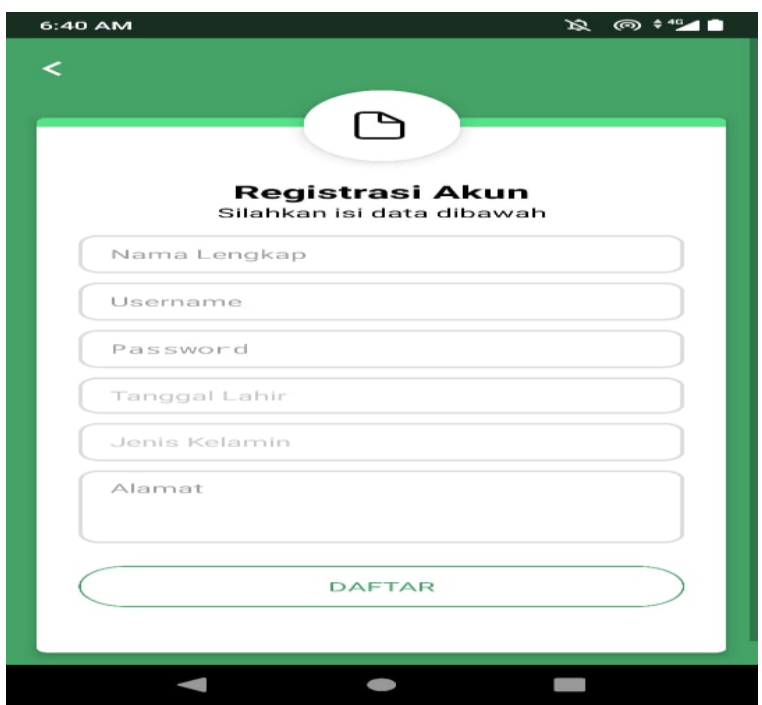

Gambar 1. Perancangan antar muka daftar member

1) Perancangan antar muka proses login

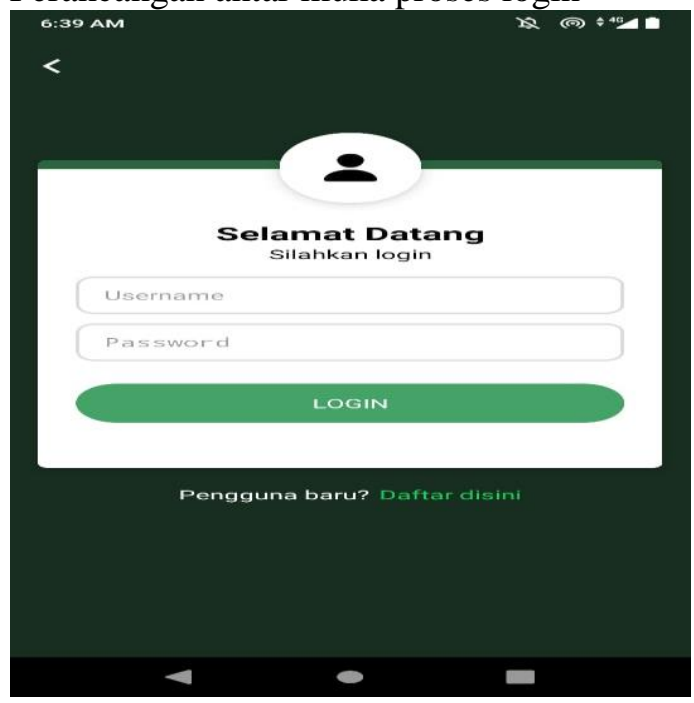

Gambar 2. Hasil perancangan tampak depan

2) Perancangan antar muka beranda
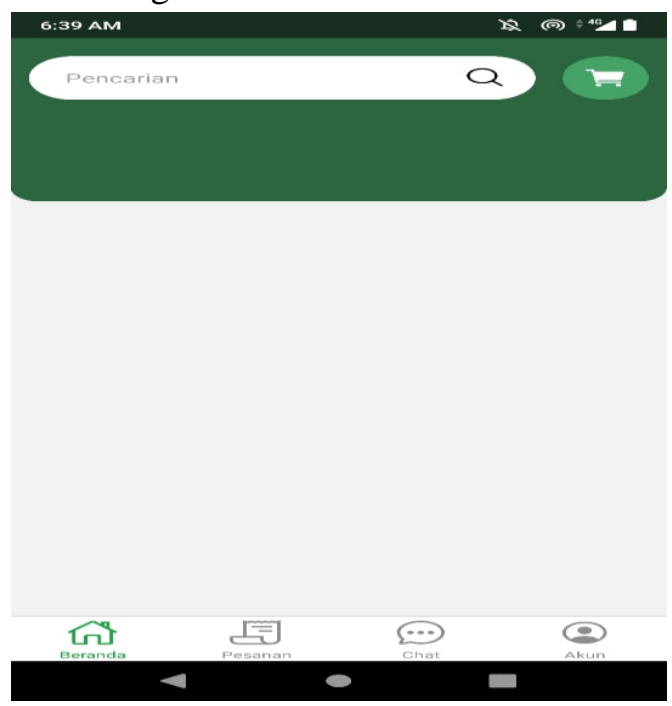

Gambar 3. Perancangan antar muka beranda 
3) Perancangan antar muka pesanan

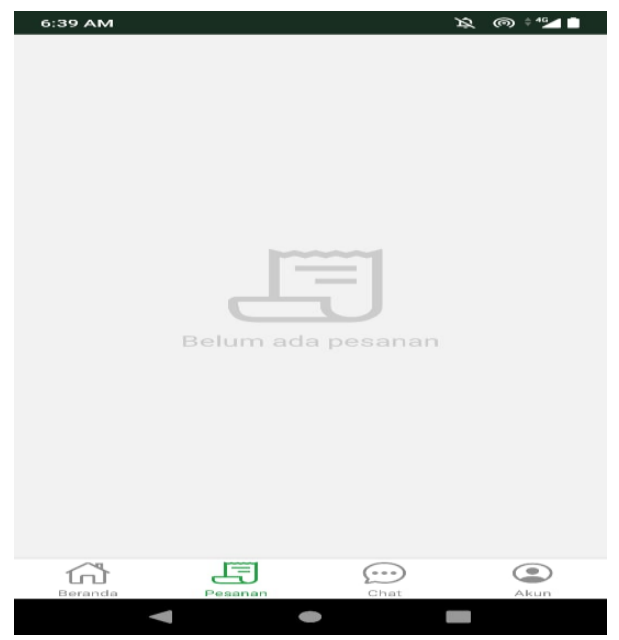

Gambar 4. Perancangan antar muka pesanan

4) Perancangan antar muka chat

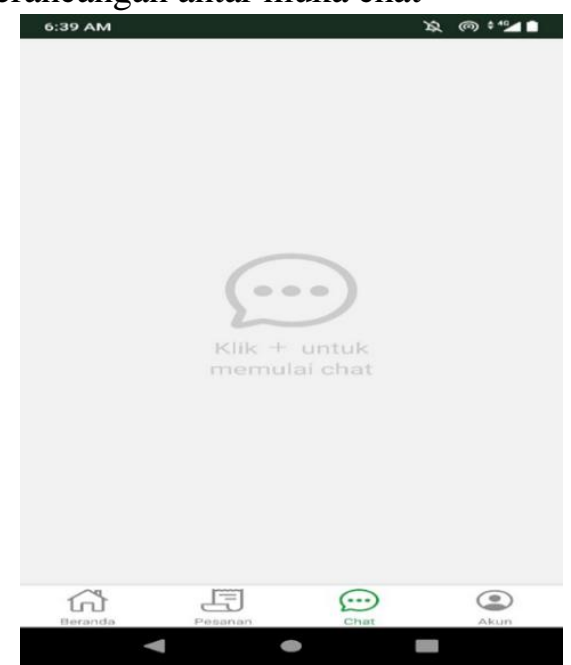

Gambar 5. Perancangan antar muka chat

\section{b. Logical Relational Structure}

Berikut rancangan database yang digambarkan menggunakan Loogical Relational Strukture:

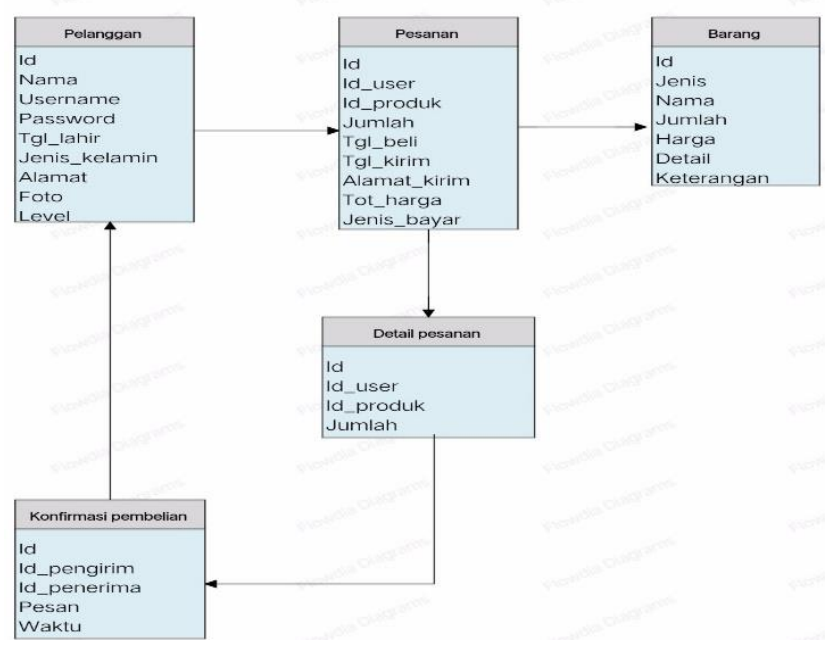

Gambar 6. Logical relational structure

\section{SIMPULAN}

Setelah dilakukan perancangan aplikasi pelayanan E-Commerce tanaman hias berbasis Android, maka dapat ditarik kesimpulan sebagai berikut:

1. Penerapan aplikasi penjualan tanaman hias ini dapat membantu pemilik toko untuk melayani pelanggan secara optimal dengan cara memberikan informasi kepada pelanggan detail dan pemesanan tanaman hias yang ada dalam aplikasi.

2. Dengan aplikasi ini pemilik toko dapat langsung melayani permintaan dari custamer.

3. Penerapan aplikasi ini dapat memudahkan pelanggan untuk membeli tanaman hias tanpa datang langsung di toko dan barang akan diantarkan di tempat tujuan.

\section{DAFTAR PUSTAKA}

[1] A. Arman and M. Saf'an, "Analisa dan Perancangan Sistem Informasi Penjualan Tanaman Hias Berbasis Online Sebagai Media Promosi Bagi Salman KS Flowers," Digital Zone: Jurnal Teknologi Informasi dan Komunikasi, vol. 10, no. 1, pp. 64-76, 2019.

[2] A. Arman, Elizamiharti, and Muhammad Saf'an, "Analisa dan Perancangan Sistem Informasi Penjualan Tanaman Hias Berbasis Online Sebagai Media Promosi Bagi Salman KS Flowers," Digital Zone: Jurnal Teknologi Informasi dan Komunikasi, vol. 10, no. 1, pp. 64 76, 2019, doi: 10.31849/digitalzone.v10i1.2346.

[3] I. Agustian, Nurhadi, "Perancangan Aplikasi Kesehatan Ibu Dan Anak (KIA) Berbasis Android," Jurnal Ilmiah Media Processor, vol. 10, no. 2, pp. 570-581, 2015.

[4] H. R. Hatta, "Perancangan," Perancangan Sistem Informasi Terpadu Pemerintah Daerah Kabupaten Paser, vol. 53, no. 9, pp. 1689-1699, 2019.

[5] L. Yudharana, T. W. Pribadi, and M. S. Arif, "Perancangan Aplikasi Berbasis Android Untuk Manajemen Proyek Pembangunan Kapal Baru," Jurnal Teknik ITS, vol. 6, no. 2, 2017, doi: 10.12962/j23373539.v6i2.25940.

[6] M. S. A. Yaqin, "Analisis Perancangan Aplikasi Layanan Laundry Berbasis Visual Basic 2010 Dan Sql Server 2000 Pada Gajayana Laundry," Semnasteknomedia Online, vol. 4, no. 1, pp. 2-9$1,2016$.

[7] M. S. A. Yaqin, "Aplikasi Pelayanan Jasa Laundry Berbasis WEB," Jurnal Teknologi Informasi, vol. 2, no. 1, p. 9, 2016. 
[8] Setiawan, A., Qomariah, N., and Hermawan, $\mathrm{H}$, "Pengaruh Kualitas Pelayanan Terhadap Kepuasan Konsumen Popolo Coffee.," Sains Manajemen Dan Bisnis Indonesia, p. 9(2), 115, 2019.

[9] S. Unnes, Android Pada Usaha Perbaikan Laptop. 2020.

[10]A. Z. Alatas, "Rancang Bangun Dan Implementasi Aplikasi Mobile Commerce Berbasis Android Di Toko Batik Qonita Pekalongan," 2013.

[11]E. Fristian, "Perancangan Sistem Informasi Penjualan Berbasis Web Pada Gerai Tanaman Hias," Repository Universitas Bina Sarana Informatika, pp. 1-64, 2018. 